DEMOGRAPHIC RESEARCH

VOLUME 37, ARTICLE 5, PAGES 101-128

PUBLISHED 13 JULY 2017

http://www.demographic-research.org/Volumes/Vol37/5/

DOI: 10.4054/DemRes.2017.37.5

Research Article

\title{
Union breakdown in West African cities: The cases of Ouagadougou and Lomé
}

\section{Bilampoa Gnoumou Thiombiano}

This publication is part of the Special Collection on "Separation, Divorce, Repartnering, and Remarriage around the World," organized by Guest Editors Benoît Laplante and Andrew Cherlin.

\section{(C) 2017 Bilampoa Gnoumou Thiombiano.}

This open-access work is published under the terms of the Creative Commons Attribution NonCommercial License 2. 0 Germany, which permits use, reproduction \& distribution in any medium for non-commercial purposes, provided the original author(s) and source are given credit. See http://creativecommons. org/licenses/by-nc/2. 0/de/ 


\section{Contents}

$\begin{array}{lll}1 & \text { Introduction } & 102\end{array}$

$2 \quad$ Context and literature review 103

3 Data and method 107

$\begin{array}{lll}3.1 & \text { Data } & 107\end{array}$

3.2 Method 108

$4 \quad$ Results 110

4.1 Union breakdown in Ouagadougou and Lomé $\quad 110$

$\begin{array}{lll}4.2 & \text { Factors associated with a union dissolution } & 117\end{array}$

$\begin{array}{lll}5 & \text { Discussion and conclusion } & 119\end{array}$

6 Acknowledgements 122

References 123 
Demographic Research: Volume 37, Article 5

Research Article

\title{
Union breakdown in West African cities: The cases of Ouagadougou and Lomé
}

\author{
Bilampoa Gnoumou Thiombiano ${ }^{1}$
}

\begin{abstract}
BACKGROUND

Marriage remains a strong institution in Africa, but union breakdown may be frequent, particularly in urban areas. However, this issue is still little studied, especially in West Africa.

\section{OBJECTIVE}

I examine the trends and factors associated with divorce and separation that lead to union breakdown in two West African cities: Ouagadougou in Burkina Faso and Lomé in Togo.

\section{METHODS}

Analyses are based on marital history data from the Economic Activities, Resourcesharing and Management of Spending in Urban Households survey, collected in 2012 in Ouagadougou and Lomé. We use the Kaplan-Meier estimator and Cox proportional hazards model for descriptive and multivariate analysis, respectively.

\section{RESULTS}

The probability of union breakdown is higher in Lomé than in Ouagadougou. The celebration of the union and having a son are associated with lower risk of divorce, while infertility or low fertility and education are associated with higher risk of divorce, for men and women in both cities. Socialization in a big town is also associated with higher risk of divorce, especially for women.
\end{abstract}

\section{CONCLUSION}

The results indicate that even if urban areas represent the ideal of modernization and social change in Africa, family and society still play an important role in union stability.

\section{CONTRIBUTION}

The consideration of both men and women in the analysis is an important contribution to the study of union breakdown in Africa.

\footnotetext{
${ }^{1}$ Institut Supérieur des Sciences de la Population (ISSP), Université Ouaga I Pr Joseph Ki-Zerbo, Burkina Faso. E-Mail: bgnoumou@issp.bf.
} 


\section{Introduction}

In the last few decades, urbanization and progress in education have led to major changes in marriage behavior in Africa (Van de Walle and Baker 2004). These include an increase in consensual unions (Calvès 2016; Legrand and Zourkaleini 2009; Thiriat 1998), a rise in age at first marriage (Hertrich 2007), and female celibacy (Antoine and Nanitelamio 1990). In the early 1970s Locoh (1976) used census data to report a rise in the median age at first marriage for women and men in Togo.

Some scholars consider these changes in marriage behavior in sub-Saharan Africa as a marriage transition, related to entry into union and marital dynamics such as union breakdown (Antoine 2002). These changes are more pronounced in urban areas because urbanization and higher levels of education lead to individual empowerment, thus weakening family and social control over couples and rendering unions less stable. Although marriage remains a strong institution in sub-Saharan Africa, union breakdown may become more frequent, particularly in urban areas where, compared to rural areas, there is less family control of couples and fewer social constraints. The frequency of women's union breakdown in West Africa is mentioned in some studies (Hertrich 2006; Lesthaeghe, Kaufmann, and Meekers 1989), but this issue is still not sufficiently studied: In particular, there are very few studies of union breakdown among men. As yet, we do not have a good understanding of the level and risk factors of union breakdown, particularly in West Africa.

The absence of adequate data is partly responsible for this situation. Censuses and Demographic and Health Surveys (DHS) are the main sources of demographic data in Sub-Saharan Africa. The censuses only collect data on the marital status of individuals, and the Demographic and Health Surveys (DHS) usually collect data on current unions. In a context where being unmarried is viewed negatively, especially in the case of women, remarriage after union breakdown often happens quickly. This cross-sectional data neither allows reconstruction of marital histories nor appropriately measures the level of union breakdown. The study of union breakdown requires data on marital histories, but this kind of data has been rarely collected in West African countries. In some research the longitudinal approach to studying unions has been adopted; at the national level (Gnoumou Thiombiano and Legrand 2014), in cities (Marcoux 1997; Antoine and Dial 2005; Antoine 2006), and on specific populations (Hertrich 2014).

This article aims to contribute to the research on marital behaviors in Africa by focusing on union breakdown in urban areas through divorce or separation. Using marital histories data, we examine the trends and associated factors of union breakdown in Ouagadougou (Burkina Faso) and Lomé (Togo), two West African cities representing different contexts. These two cities are characterized by high population growth linked to rural-urban mobility and are linked by trade. Lomé, a coastal town, is 
usually cited as an example of the economic dynamism of women (e.g., Nana Benz²), while Ouagadougou is a landlocked Sahelian city. Women's contribution to household income is more important in Lomé, where most women are active in trade (facilitated by access to the sea), than in Ouagadougou. Therefore, gender relations in the two cities might differ and there may be differences in the trends and factors associated with divorce and separation.

I first analyze and compare the trends in divorce and separation in the two cities. Then I explore factors associated with divorce and separation for men and women separately. The results can help us to better understand divorce and separation in West Africa.

This paper is structured as follows. Section 2 provides an overview of the context and a literature review. Section 3 is devoted to data description and methods. The results are then presented in section 4, and the final section summarizes and discusses outcomes.

\section{Context and literature review}

Compared to eastern and southern African countries, West African countries are characterized by earlier ages at first marriage for women, low rates of permanent celibacy, and relatively few consensual unions. Traditionally, marriage means the union of a man and a woman, in a socially recognized framework, in order to form a family. In Burkina Faso and Togo various types of wedding exist: religious marriages sanctified by a celebration in a mosque or church, civil marriages performed by a civil officer, and traditional marriages in which a woman joins her future husband after a traditional solemnization. These forms of union are not exclusive. A union can be solemnized by all three types of wedding, or by two, or by only one. However, civil marriages are less common in both countries, particularly in rural areas: Couples can get a religious marriage or traditional marriage anywhere, but civil marriage with legal effects is an urban affair and mainly for educated people. In this study we consider all types of union, including civil, religious, and traditional unions and also informal unions, which in both countries' population censuses are defined as a woman (or a man) being considered as in a union when s/he declares herself as such.

The union dissolution can occur through death of one spouse (widowhood) or by divorce or separation. In the context of this study, divorce in most cases is not legalized and union breakdown is not registered. Sometimes women in particular prefer to declare themselves separated in order to maintain a better social status. Thus, in this

\footnotetext{
2 'Nana Benz' is the name attributed to a wealthy tradeswoman in Togo.
} 
study we consider both divorce and separation. In Africa divorce incurs the censure of both families and society as it is considered a challenge to family alliances. Some authors have argued that women use divorce as a strategy to improve their position throughout their life course (Locoh and Thiriat 1995).

Although in Burkina Faso and Togo, as in other African countries, unions are not considered to be indissoluble, divorce and separation are not appreciated. According to the family code of Burkina Faso (Code des Personnes et de la Famille, Article 354), divorce may result from the mutual consent of the spouses pronounced by a civil court, or from a judicial decision ordering the dissolution of union at the request of one spouse (MASF Burkina Faso 1990). This is also the case in Togo, where the family code also specifies both types of divorce (Assemblée Nationale Togolaise 2012): divorce by mutual consent on request of both spouses (Article 117) and litigation divorce at the request of either spouse (Article 126). However, in both countries the breakdown of union usually occurs through a separation caused by the departure of the wife from the matrimonial home, without any judicial or traditional proceedings. Even in civil marriages, couples rarely turn to the courts to resolve their separation or divorce because of the social sanction. Thus, in this study, we consider a union's breakdown as when it ends in divorce or separation.

Research has revealed profound changes in marriage behavior in West African countries (Clark and Brauner-Otto 2015), particularly in urban areas (Marcoux and Antoine 2014). Antoine (2006) observes changes in marriage practices in several African cities, including Lomé. By analyzing the data in biographical surveys, these authors show the emergence of new forms of marital arrangement, including, in Lomé, consensual unions outside traditional requirements.

In Western countries, marriage behavior has been studied within various disciplines: demography, sociology, psychology, economy, law, etc. (White 1990). However, in Africa, marriage behavior, including union breakdown, is still little studied. If polygamy and entry into first marriage have attracted some interest in research (Lesthaeghe, Kaufmann, and Meekers 1989; Hertrich 2006), this is not the case for union breakdown, which has been the focus of very few studies. Divorce, like widowhood, has been studied mainly for its possible influence on fertility. Divorce has also been addressed in studies on polygamy, as a positive factor.

However, in recent years the collection of biographical data in some African countries has allowed researchers to conduct longitudinal analysis of marriage behavior. These studies have revealed a marriage transition in terms of age at first marriage, age difference between spouses, separation, divorce, and remarriage. These changes in marital behavior may reflect deep changes in family organization and gender relations. The biographical approach allows analysis of the evolution of divorce, and the identification of demographic, economic, and social factors associated with divorce 
(Thiriat 1998; Dial 2007; Gnoumou Thiombiano and Legrand 2014). Divorce appears more and faster in the younger generations and is more common in urban than rural areas (Takyi 2001; Antoine and Dial 2005). In Burkina Faso, at the national level, about $10 \%$ of married women's first unions break down through separation or divorce within the first 10 years (Gnoumou Thiombiano and Legrand 2014). In Dakar one union in three ends in divorce, and among the younger generations, one in four women divorce in the first seven years of union (Antoine and Dial 2005). This marital instability is often understood as a desire for emancipation or as a source of social promotion for women (Thiriat 1998; Dial 2007). Thus, in several studies, union breakdown is not considered as a single event but rather as a process of family change. Indeed, several researchers focus on the consequences of divorce for spouses, especially women, and for children's wellbeing (Chae 2013; Gnoumou Thiombiano, Legrand, and Kobiané 2013; Cherlin, Kiernan, and Chase-Lansdale 1995).

In the past decades the literature has focused on social and economic determinants of the risk of divorce. Age at marriage is one of the strongest predictors of marital dissolution (Antoine and Dial 2005; Tilson and Larsen 2000; Clarke and Berrington 1999; South 1995; Bumpass, Martin, and Sweet 1991): early marriage increases the risk of divorce. In Togo nearly $23 \%$ of first unions end in divorce when the marriage took place before the age of 20, and 18\% when the union is celebrated later (Thiriat 1998). The explanatory hypotheses of the effect of early marriage on divorce are that very young married individuals have not taken enough time to know their spouses well (Becker, Landes, and Michael 1977; Thornton and Rodgers 1987), and that they are poorly prepared to assume their marital roles (Booth and Edwards 1985; Amato and Previti 2003). According to Locoh (2000), in Africa early marriage, usually arranged by the families, is a sort of 'rite of passage' for girls to acquire adult status. This marriage is often experienced as a constraint that the woman tries to break by divorce in order to marry a man of her choice.

Education is also associated with the risk of divorce, particularly for women (South 1995; Hoem 1997). In Africa this effect is especially significant in urban areas where the women are more educated. For example, in Lomé and Dakar educated women have greater risks of divorcing than those who are not educated (Antoine and Dial 2005). There is no specific study on Ouagadougou, but in Burkina Faso educated women are more likely to divorce than those who are not educated (Gnoumou Thiombiano and Legrand 2014).

Infertility or low fertility of the couple is an important factor in divorce in African countries, particularly for woman (Takyi 2001). For example, in Burkina Faso women without children and those with one child have a higher risk of divorce than those with four children (Gnoumou Thiombiano and Legrand 2014). In rural Togo, infertile couples' risk of divorce is twice that of those who have children (Thiriat 1998). The 
presence of children seems to consolidate the union. Becker and colleagues (1977) observe that children constitute marital-specific capital and consequently should reduce the risk of parents divorcing. Cherlin (1977) notes that children constitute a barrier to divorce, especially when they are very young (preschool ages), when the motivation to maintain a conflicted marriage may be especially strong.

Economic problems, including unemployment of the husband, are also associated with a high risk of divorce. In African societies the husband is obliged to pay the household expenses, and failure to do so can disrupt the union. On the other hand, the employment of women, which can give them financial independence, is also associated with a high risk of divorce (Vignoli and Ferro 2009; Takyi and Broughton 2006). According to the economic hypothesis, the likelihood of divorce is increased if women work for pay and have attractive labor market resources (Becker, Landes, and Michael 1977). Women's employment increases their independence and their risk of divorce in the case of relationship conflict because they are able economically to support their household. In Dakar, economically independent women - for example, salaried women - divorce faster than those who are in a precarious financial situation (Dial 2007). Several authors have argued that the rise in divorce in some western countries is partly due to the growing autonomy of women in society. According to the economic marriage hypothesis, the autonomy of women through their participation in labor reduces the benefits of marriage and increases the risk of divorce (e.g., Ruggles 1997; Oppenheimer 1994, 1997). However, the factors associated with the risk of divorce are not only economic. In Africa, marriage is an important social institution that cannot be reduced to an economic relationship between spouses.

Several studies find an association between polygamy and divorce of women. Polygamy promotes the divorce and remarriage of women by enabling them to quickly find a new partner and, conversely, divorced women supply the polygamy market (e.g., Pison 1988). Women in monogamous unions divorce less than those in polygamous unions, as the arrival of a second wife in the household can lead to the divorce of the first wife (Gnoumou Thiombiano and Legrand 2014).

However, as noted earlier, the cross-sectional data used for some previous studies is limited when studying marital dynamics. Since the risk of union dissolution depends on the length of exposure to the risk it is necessary to take into account the duration of the union in the analysis, which is possible by analyzing biographies. However, the use of this method requires biographical information like that used in this study. 


\section{Data and method}

\subsection{Data}

The data for this study is from the Economic Activities, Resource-Sharing and Management of Spending in Urban Households survey, conducted in 2012. The survey data was collected as part of the research project Family, Gender and Activities in SubSaharan Africa, funded by the Agence Nationale pour la Recherche (ANR). This research project was led by the Laboratoire Population Environnement Développement (LPED) of the Institut de Recherche pour le Développement (IRD) and Université AixMarseille (France), Institut Supérieur des Sciences de la Population (ISSP) at the Université Ouaga I Pr Joseph Ki-Zerbo (Burkina Faso), Centre de Formation et de Recherche en Population (CEFORP) at the Université d'Abomey (Benin), and Unité de Recherche Démographique (URD) of the Université de Lomé (Togo). The main objective of the research was to analyze the evolution of gender roles in families in African cities.

Data was collected using the same methodology in Lomé and Ouagadougou, with two types of questionnaire, a household questionnaire and an individual questionnaire. In each city data was collected from 500 households, and in each household all resident men and women age 18 years and over were interviewed. Like other household surveys, the sampling is based on the list of enumeration areas of Ouagadougou and Lomé made during the last population censuses conducted in Burkina Faso (2006) and Togo (2010). The survey has two-stage cluster sampling. In the first stage, 25 enumeration areas were selected in each district of the city according to the proportional probability of population size. In the second stage, 20 households were selected in each enumeration area. Households were selected by using a step number, which is calculated by dividing the total number of household in the enumeration areas by 20 . Interviewers surveyed heads of households to determine whether eligible men and women resided there. All men and women aged at least 18 years old living in selected households were eligible to be interviewed.

Interviews were completed with 1,149 individuals in Ouagadougou and 1,156 individuals in Lomé. In this paper we consider all men and women who had been in a union during their life, 776 individuals ( 325 men and 451 women) in Ouagadougou and 780 (302 men and 478 women) in Lomé. The survey is cross-sectional, but it collected information on marital history for men and women aged at least 18 years old. For each union, information was collected on the date of the union, the dates of union celebrations, and the type and the date of union breakdown for those that ended. Other information collected was date of birth, ethnicity, education, activities, residence, etc. 
This data allows us to explore trends in union breakdown and factors associated with divorce in West African urban areas.

The data is appropriate for our analysis because, in contrast to data from censuses and most other surveys, this data provides marital histories. However, the data has some limitations, whose effects should not substantially alter the results. First, very little information has been collected on the partner, and as the risk of divorce depends on both spouses it would be well to consider certain characteristics of the partner in the analysis. For example, we cannot take into account the age difference of spouses because the survey did not collect information on the partner's age. Second, the variable 'polygamy,' often taken into account in the analysis of divorce in Africa, cannot be considered because information on polygamy was collected only for women at the time of entry into union. There was no information on polygamous status changes that occurred during a union. Third, the information on activities was collected only at the time of survey, which does not represent the situation at the moment they occurred. Fourth, our sample is selective because only women and men who survived and did not emigrate were interviewed. The emigrants might have specific characteristics that could influence their risk of divorce. Fifth, retrospective surveys are prone to inaccurate, incomplete, or partial reporting of responses. For example, divorce occurring immediately after marriage might be underreported and result in the underestimation of divorce.

\subsection{Method}

Survival data analysis methods, specifically the Kaplan-Meier estimator and Cox proportional hazards model, are used to analyze marital history data. These methods provide a set of statistical techniques for studying the calendar of events, changes in the state of an individual during his/her life, and the factors associated with these changes. It is suitable for the study of events which part of the study population has not experienced, like divorce. The Cox method allows combining in the analysis the effect of time and taking into account different characteristics of the individual that may explain an event (Cleves, Gould, and Gutierrez 2004).

The event of interest is union breakdown by divorce or separation. The analysis time is the duration of the union, calculated as the difference between the end date of the union, or the date of the survey for women and men who are still in their union (right censoring), and the start date of the union. Widows are considered as exposed to the risk of divorce or separation from the start of the union to death of the spouse.

The main explanatory variables are union cohort, union formalization, and education. The variable 'union cohort' is classified into three groups: people who were 
married before 1980, those who were married between 1980 and 1999, and those who were married between 2000 and 2012. This variable measures the effect of the local context of the union on the risk of divorce, and allows examining differences in the risk of divorce over the time. The period 1980-1990 was marked by the democratic revolution in Burkina Faso (1983-1987) and an economic crisis in both countries. Education is often used as a proxy for autonomy and empowerment. Education, recognized as a factor of change in individual behavior, could be associated with a higher risk of divorce. For example, in Dakar educated women have a greater risk of divorce than those who are not educated (Antoine and Dial 2005). In this study the variable 'education' is coded as no education, primary education, and secondary or above secondary education. Union formalizations are measured by the number of solemnizations performed. The formalization of a union reflects its social recognition and contributes to its stability. In West Africa, as we have already noted, there are three ways to solemnize a union. For analysis we disaggregated unions into three categories: those with two or three solemnizations, those with one solemnization, and those with no solemnization. Ideally, it would have been better to consider the type of solemnization, but because of low sample numbers this was not possible (this variable should include 6 categories).

Other control variables included in the models, based on the available data and previous studies, are age at union, ethnic composition of couple, rank of union, place of socialization, number of children in the union, and having at least one son in the union. In the analysis, age at union is disaggregated into three categories for men $(<25$ years, 25-29 years, and $\geq 30$ years old) and three categories for women $(<18$ years, 18-24 years, and $\geq 25$ years). These categories take into account the mean age at union for men (Ouagadougou: 28.8 years, Lomé: 26.6 years) and women (Ouagadougou: 19.7, Lomé: 20.7). The variable 'ethnic composition of couple' aims to capture the effect of ethnic heterogeneity on divorce risk due to cultural differences between ethnic groups. This variable is coded as a dummy variable, with 1 indicating a homogamous couple and 0 indicating a heterogamous couple. The rank of the union aims to identify differences in divorce risk between the first union and subsequent unions. For example, social and family controls are less strong for remarriage than for first union. Thus, remarriages could be at higher risk of divorce than first unions. This variable was coded into two categories: first union and second union and above (there are very few remarriages in the sample). The place of socialization is place of residence at a young age (6 years old). This variable reflects the context of men and women at a young age. The variable 'number of children of the union' aims to observe the effect of children on the risk of divorce. Three categories are considered: no child, 1-2 children, and 3 children or more. Because of boys' social position in African societies, we assume that having a son can reduce the risk of separation and divorce. The variable 'having at least one son' 
aims to captures this effect. This variable was coded as a dummy variable, with 1 indicating men and women who have at least one son in their union and 0 indicating those who have no son.

Table 1 provides descriptive statistics of the variables used in the analysis. The sample used for the study comprises 776 individuals in Ouagadougou and 780 individuals in Lomé. Informal unions and remarriages are more frequent in Lomé than in Ouagadougou for both men and women. Men and women in Lomé are more educated than those in Ouagadougou. About $32 \%$ of men and $51 \%$ of women have no education in Ouagadougou; these proportions are respectively about $4 \%$ and $25 \%$ in Lomé. However, in both cities, men are more educated than women. The number of ethnically homogamous unions is high in both cities: about 8 in 10 unions are homogamous. Almost 4 in 10 unions have no son.

\section{Results}

\subsection{Union breakdown in Ouagadougou and Lomé}

Kaplan-Meier curves are used to examine men and women's survival to union breakdown. The curves show the proportion of surviving men and women by union duration in years. This analysis was conducted for the three main variables by gender.

Figure 1 shows the survival curve for breakdown of union by gender in Ouagadougou and Lomé. The results show that for both men and women the probability of union breakdown is especially high within the first 15 years of the union. After 15 years this probability is substantially reduced for men and women in both cities. These results show that the stability of the union increases with its duration: Over time the couple may be better able to ensure cohesion of their union. This result has also been found in previous research at the national level in Burkina Faso (Gnoumou Thiombiano and Legrand 2014). In the first 20 years after union, about 7\% of women and $9 \%$ of men divorce or separate in Ouagadougou, but there is no significant difference between men and women according to the log-rank test. In Lomé women have a higher probability of divorcing than men: $17 \%$ of women and $15 \%$ of men have a breakdown in their union within the first 20 years. These results are similar to those in the study of Antoine and Dial (2005) in Lomé. Compared to Ouagadougou, the probability of divorce is higher in Lomé, but compared to several other West African cities like Dakar (Senegal), the probability of union dissolution in the two cities is relatively low. 
Table 1: Descriptive statistics for all variables use in the analysis, Ouagadougou and Lomé

\begin{tabular}{|c|c|c|c|c|c|c|c|c|}
\hline \multirow{3}{*}{ Variable } & \multicolumn{4}{|c|}{ Ouagadougou ( $\mathrm{N}=776)$} & \multicolumn{4}{|c|}{ Lomé ( $\mathrm{N}=780)$} \\
\hline & \multicolumn{2}{|r|}{ Men } & \multicolumn{2}{|c|}{ Women } & \multicolumn{2}{|c|}{ Men } & \multicolumn{2}{|c|}{ Women } \\
\hline & Number & Percent & Number & Percent & Number & Percent & Number & Percent \\
\hline \multicolumn{9}{|l|}{ Union cohort } \\
\hline Before 1980 & 30 & 9.23 & 70 & 15.52 & 40 & 13.25 & 83 & 17.36 \\
\hline 1980-1999 & 106 & 32.62 & 162 & 35.92 & 120 & 39.74 & 197 & 41.21 \\
\hline 2000-2012 & 189 & 58.15 & 219 & 48.56 & 142 & 47.02 & 198 & 41.42 \\
\hline \multicolumn{9}{|l|}{ Union celebration } \\
\hline Two or three celebrations & 186 & 57.23 & 273 & 60.53 & 89.00 & 29.47 & 135.00 & 28.24 \\
\hline One celebration & 109 & 33.54 & 143 & 31.71 & 156.00 & 51.66 & 240.00 & 50.21 \\
\hline No celebration & 30 & 9.23 & 35 & 7.76 & 57.00 & 18.87 & 103.00 & 21.55 \\
\hline \multicolumn{9}{|l|}{ Age at union } \\
\hline$<25$ years & 95 & 29.23 & - & - & 127 & 42.05 & - & - \\
\hline $25-29$ years & 120 & 36.92 & - & - & 94 & 31.13 & - & - \\
\hline$\geq 30$ years & 110 & 33.85 & - & - & 81 & 26.82 & - & - \\
\hline$<18$ years & - & - & 130 & 28.82 & & & & \\
\hline $18-24$ years & - & - & 244 & 54.10 & - & - & 130 & 27.20 \\
\hline$\geq 25$ years & - & - & 77 & 17.07 & - & - & 246 & 51.46 \\
\hline Ethnic homogamy & & & & & - & - & 102 & 21.34 \\
\hline Yes & 244 & 75.08 & 340 & 75.39 & 235 & 77.81 & 372 & 77.82 \\
\hline No & 81 & 24.92 & 111 & 24.61 & 67 & 22.19 & 106 & 22.18 \\
\hline \multicolumn{9}{|l|}{ Ranking of union } \\
\hline First union & 304 & 93.54 & 446 & 98.89 & 238 & 78.81 & 430 & 89.96 \\
\hline Second union and above & 21 & 6.46 & 5 & 1.11 & 64 & 21.19 & 48 & 10.04 \\
\hline \multicolumn{9}{|l|}{ Education } \\
\hline None & 103 & 31.69 & 230 & 51.00 & 13 & 4.30 & 118 & 24.69 \\
\hline Primary & 85 & 26.15 & 95 & 21.06 & 78 & 25.83 & 170 & 35.56 \\
\hline Secondary and above & 137 & 42.15 & 126 & 27.94 & 211 & 69.87 & 190 & 39.75 \\
\hline \multicolumn{9}{|l|}{ Place of socialization } \\
\hline Ouagadougou/Lomé & 112 & 34.46 & 158 & 35.03 & 125 & 41.39 & 220 & 46.03 \\
\hline Other city & 79 & 24.31 & 101 & 22.39 & 67 & 22.19 & 104 & 21.76 \\
\hline Rural & 104 & 32.00 & 142 & 31.49 & 76 & 25.17 & 80 & 16.74 \\
\hline Foreigner & 30 & 9.23 & 50 & 11.09 & 34 & 11.26 & 74 & 15.48 \\
\hline \multicolumn{9}{|c|}{ Number of children in union } \\
\hline None & 51 & 15.69 & 59 & 13.08 & 30 & 9.93 & 40 & 8.37 \\
\hline $1-2$ children & 142 & 43.69 & 177 & 39.25 & 140 & 46.36 & 211 & 44.14 \\
\hline$\geq 3$ children & 132 & 40.62 & 215 & 47.67 & 132 & 43.71 & 227 & 47.49 \\
\hline \multicolumn{9}{|c|}{ Have at least one son in union } \\
\hline Yes & 184 & 56.62 & 285 & 63.19 & 201 & 66.56 & 302 & 63.18 \\
\hline No & 141 & 43.38 & 166 & 36.81 & 101 & 33.44 & 176 & 36.82 \\
\hline $\mathbf{N}$ & 325 & 100 & 451 & 100 & 302 & 100 & 478 & 100 \\
\hline
\end{tabular}


Figure 1: Survival curve to divorce or separation in Ouagadougou and Lomé, by gender (Kaplan-Meier survival function)

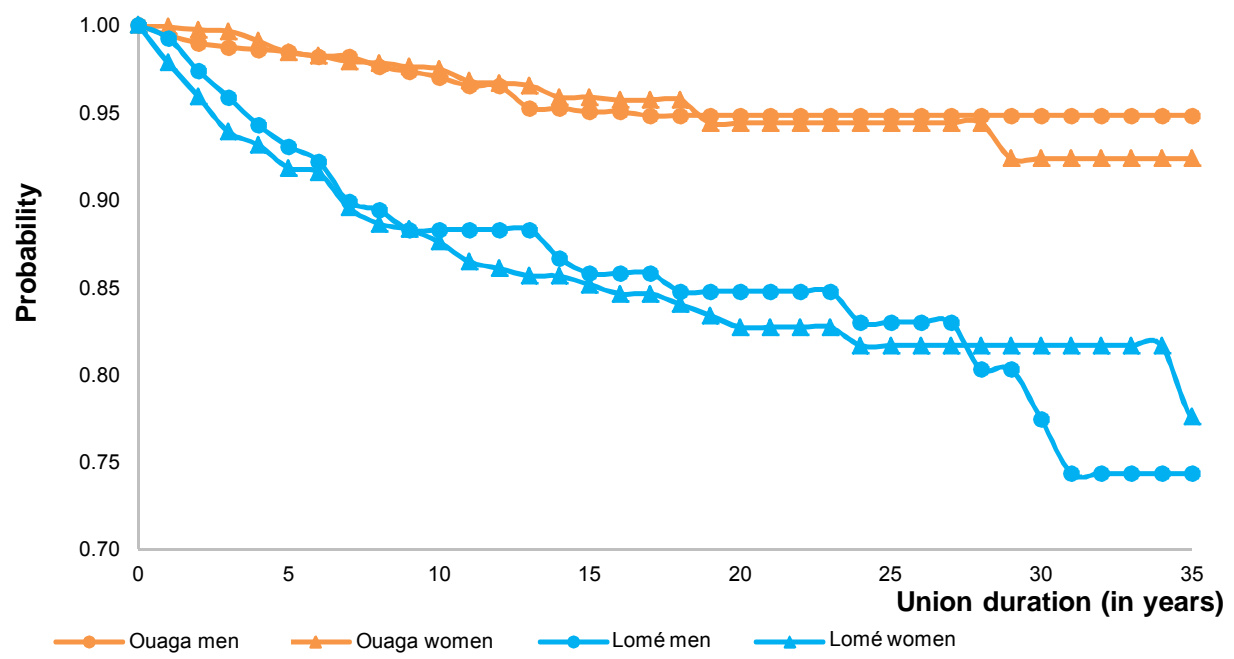

Figure 2 shows the differences in union between union cohorts. Contrary to what we expected, the results show that, for men, the probability of divorce is higher among older cohorts than the younger cohort in Ouagadougou and Lomé. This is also the case for women in Lomé. However, for women in Ouagadougou, as expected, the younger union cohorts have a higher risk of divorce than the older cohort. As observed for all men and women, for each union cohort the probability of union breakdown is higher in Lomé than in Ouagadougou. But the differences between union cohorts are significant for men and women in both cities according to the log-rank test $(\mathrm{p}<0.5)$. About $22 \%$ of women married before 1980 and 16\% of women married between 1980 and 1999 are divorced in Lomé within 20 years after the union. In Ouagadougou the probabilities are lower, $2 \%$ and $6 \%$ respectively. 
Figure 2: Survival curve to divorce or separation in Ouagadougou and Lomé, by union cohort, for men and women (Kaplan-Meier survival function)

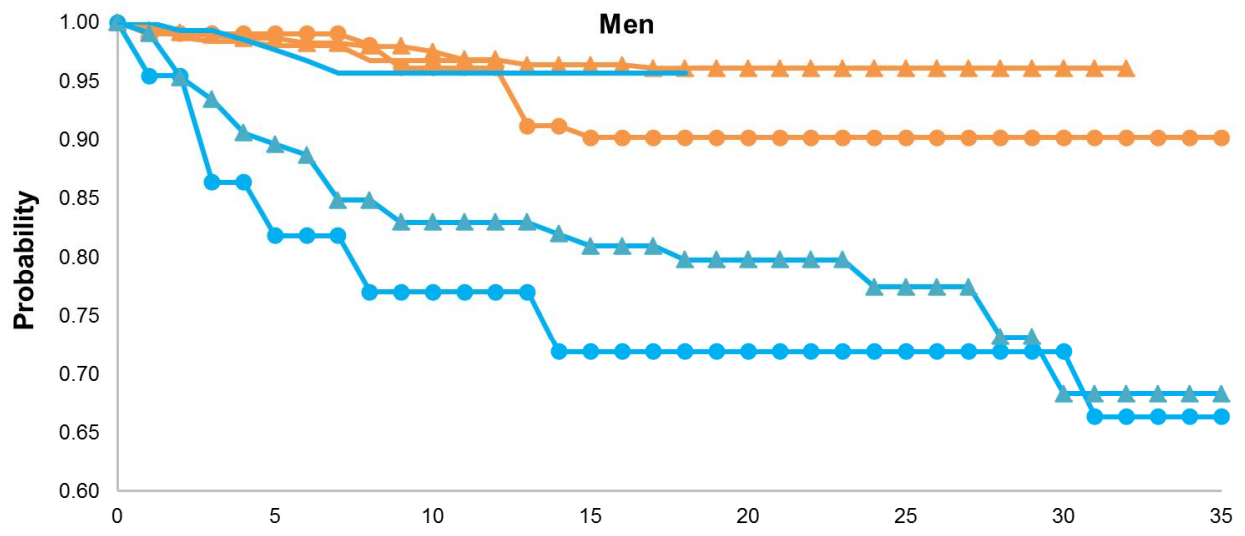

Union duration (in years)
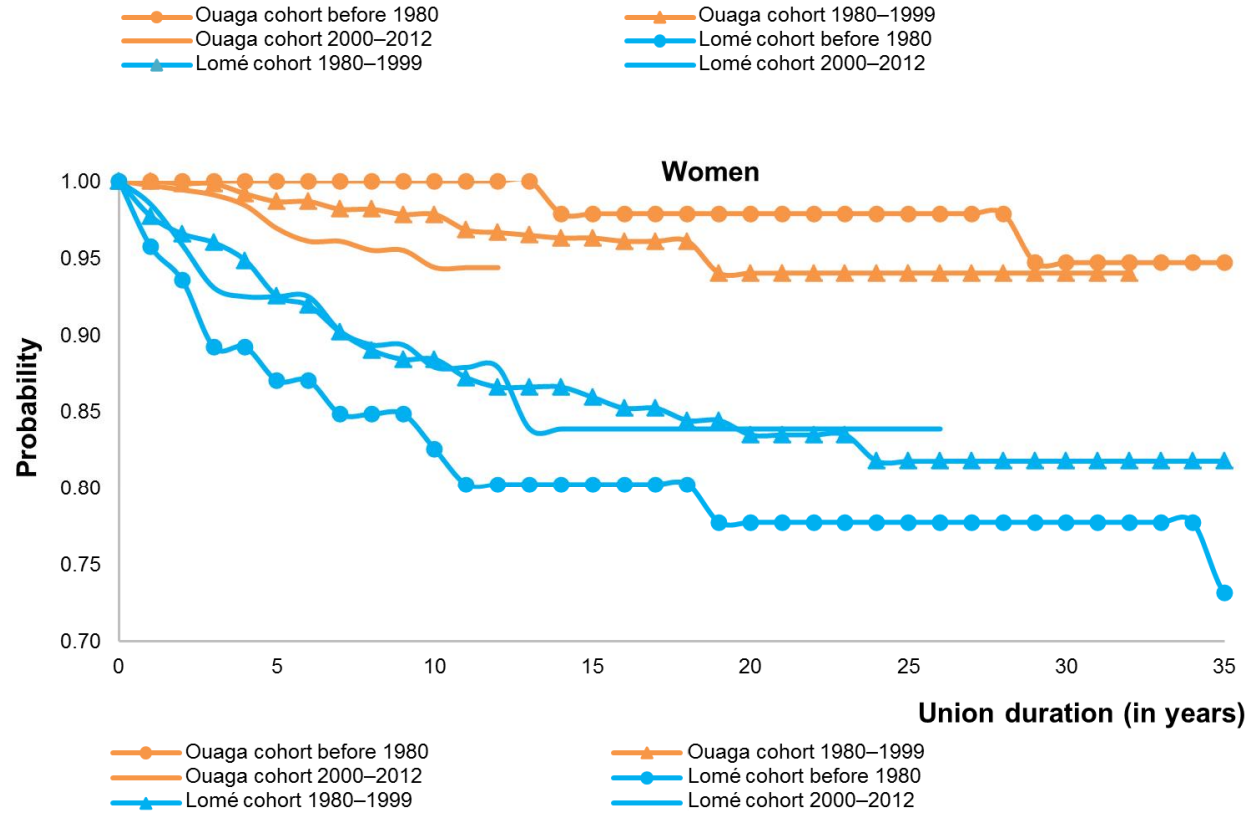
The probability of divorce by the number of union celebrations is presented in Figure 3. As expected, the probability of divorce is higher for informal unions (without any celebration) for men and women than for formal unions. The differences are significant for men and women in both cities $(\mathrm{p}<0.001)$. For example, in Lomé during the first ten years of union, $33 \%$ of men in informal unions, $9 \%$ of those whose union had one celebration, and about $2 \%$ of those whose unions had at least two types of celebration divorced. For women in Lomé, respectively, 30\%, 6\%, and 3\% of unions divorced during the first ten years of union. The same trends are observed for men and women in Ouagadougou.

Figure 3: Survival curve to divorce or separation in Ouagadougou and Lomé, by union celebration, for men and women (Kaplan-Meier survival function)

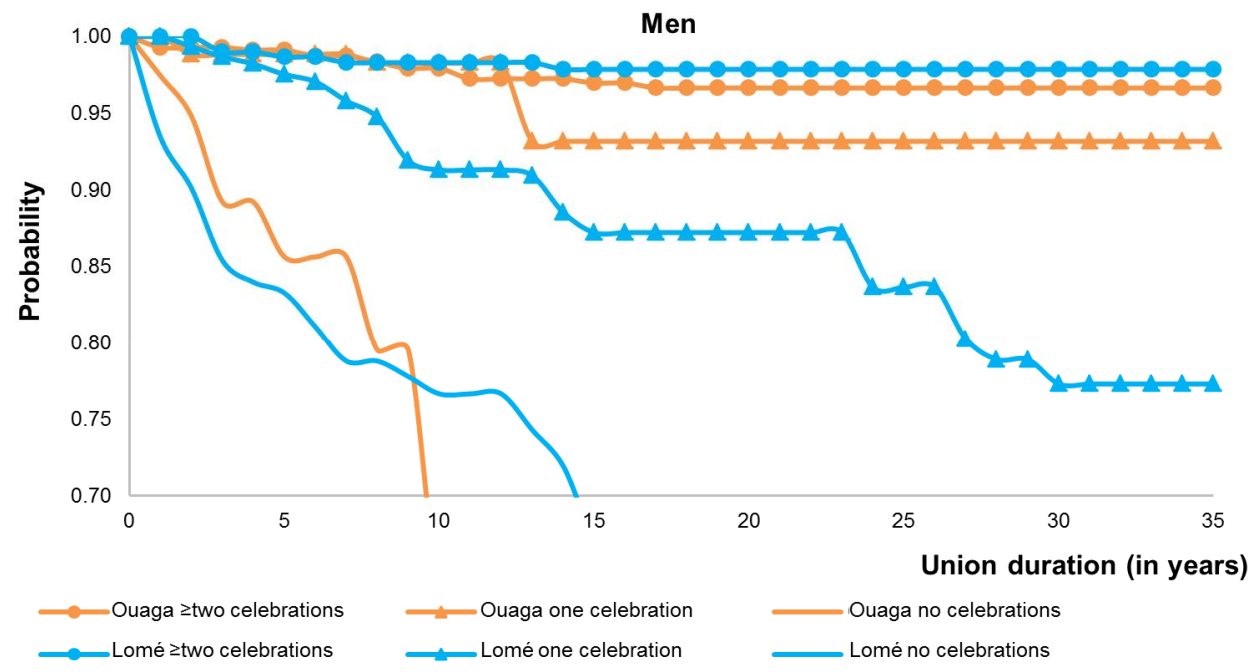


Figure 3: (Continued)

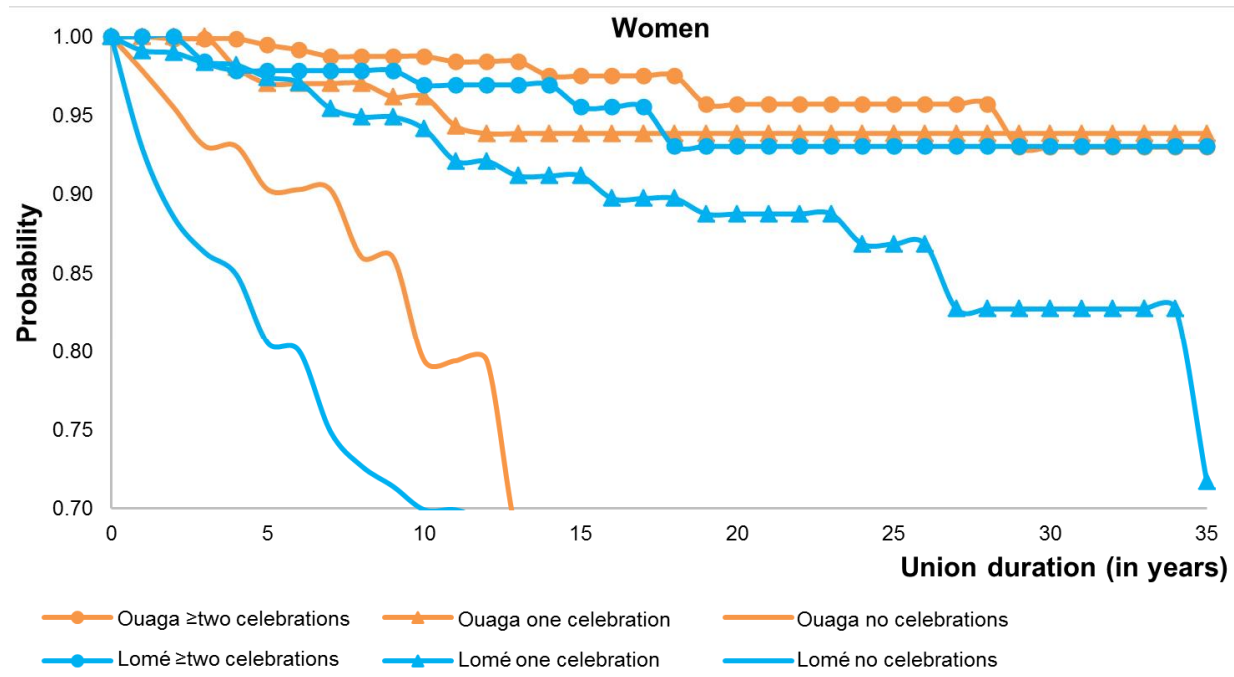

Figure 4 shows differences according to men's and women's education. In both cities, educated men and women have a higher probability of divorce than those who do not. The differences are significant $(\mathrm{p}<0.001)$ excepted for men in Lomé. The probability is especially high for those with primary education. However, in Lomé, after 15 years of marriage, educated men seem to have a lower probability of divorce than the uneducated. 
Figure 4: Survival curve to divorce or separation in Ouagadougou and Lomé, by education, for men and women (Kaplan-Meier survival function)
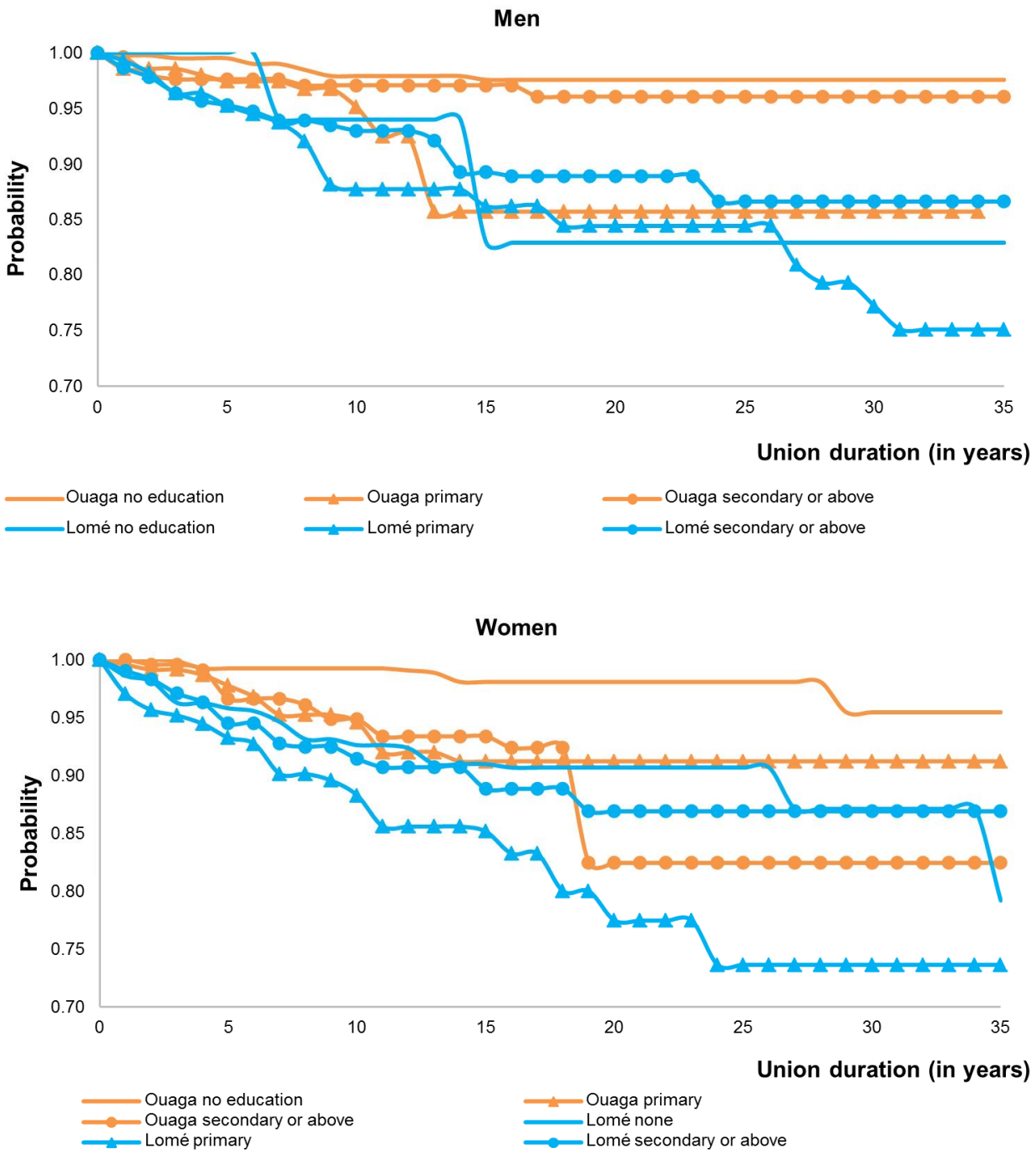


\subsection{Factors associated with a union dissolution}

The table below presents the results of four Cox proportional hazard models. The first two models analyze the union's dissolution for men in Ouagadougou and Lomé, and the last two models show the results for women in the two cities. For each independent variable the table shows the odds ratio for each group compared to the reference category. The odds ratio shows how much the divorce risk is reduced or increased by changes in the independent variable. Thus we can identify the factors that accelerate and those that slow the risk of divorce.

Contrary to our expectations, there is no significant difference between the union cohorts in either city for men and women. Women's education is associated with a higher risk of their union dissolution only in Ouagadougou; this effect is not significant in Lomé. Education does not have a significant effect on men union's dissolution in either city.

There is no significant difference between union cohorts in either city when other variables are controlled for, except for men in Ouagadougou where the union cohort 1980-1999 had less risk of divorce than the older cohort (before 1980). However, those who married in the earlier period have had longer exposure to marriage than those who married in the recent period. The formalization of union is associated with the risk of union breakdown for men and women in both cities. In both Ouagadougou and Lomé, unions without any solemnization have a higher risk of union breakdown than those who experienced at least two types of solemnization. The risk is particularly high for men in Lomé, where it is 26 times higher for those who had no solemnization. Women in an informal union are about nine times more at risk of divorce than women who experienced at least two types of solemnization. In Ouagadougou the risk for women from the first group is about three times higher than for women from the latter. As expected, education is associated with a higher risk of union breakdown in both cities, except for men in Lomé, for which this effect is not significant. The effects of education are especially important in Ouagadougou, where the education level is lower than Lomé. In Ouagadougou, primary-educated men and women are six and four times more at risk of divorce, respectively, than those without education. Our results are consistent with previous research in sub-Saharan Africa (Amoatang and Heaton 1989; Takyi 2007). 
Table 2: Hazards ratio for Cox regression models of divorce or separation for men and women in Ouagadougou and Lomé

\begin{tabular}{|c|c|c|c|c|}
\hline \multirow{3}{*}{ Variables } & \multicolumn{4}{|c|}{ Hazards ratio } \\
\hline & \multicolumn{2}{|c|}{ Men } & \multicolumn{2}{|c|}{ Women } \\
\hline & Ouagadougou & Lomé & Ouagadougou & Lomé \\
\hline \multicolumn{5}{|c|}{ Union cohort (before 1980) } \\
\hline 1980-1999 & $0.401^{*}$ & 1.287 & 1.463 & 0.777 \\
\hline 2000-2012 & 0.340 & 0.644 & 1.235 & 0.783 \\
\hline \multicolumn{5}{|c|}{ Union celebration (Two or three celebrations) } \\
\hline One celebration & 1.334 & $8.851^{\star * *}$ & 1.754 & $2.506^{\star \star \star}$ \\
\hline None celebration & 2.554 & $26.470^{\star \star \star}$ & $2.933^{*}$ & $6.827^{\star \star \star}$ \\
\hline \multicolumn{5}{|c|}{ Age at union ( $\geq 30$ years / $\geq 25$ years) } \\
\hline$<25$ years & $2.649^{*}$ & 1.069 & - & - \\
\hline $25-29$ years & 0.861 & 0.635 & - & - \\
\hline$<18$ years & - & - & 0.916 & $0.446^{\star \star \star}$ \\
\hline $18-24$ years & - & - & 1.922 & $0.484^{\star \star *}$ \\
\hline \multicolumn{5}{|l|}{ Ethnic homogamy (Yes) } \\
\hline No & 1.026 & 1.286 & $0.490^{*}$ & 1.280 \\
\hline \multicolumn{5}{|c|}{ Ranking of union (First union) } \\
\hline Second union and above & $2.883^{*}$ & $7.249^{* * *}$ & $6.881^{\star \star \star}$ & $6.202^{\star \star \star}$ \\
\hline \multicolumn{5}{|l|}{ Education (None) } \\
\hline Primary & $5.574^{\star \star *}$ & 0.448 & $3.966^{* \star \star}$ & $1.707^{* *}$ \\
\hline Secondary and above & 1.650 & 0.490 & $3.531^{* \star}$ & 1.004 \\
\hline \multicolumn{5}{|c|}{ Place of socialization (Rural) } \\
\hline Ouagadougou/Lomé & 0.947 & 1.055 & $2.622^{* *}$ & $1.652^{*}$ \\
\hline Other city & 0.450 & $1.976^{*}$ & 0.8196 & 0.695 \\
\hline Foreigner & 0.885 & 1.615 & $3.088^{* *}$ & 0.587 \\
\hline \multicolumn{5}{|c|}{ Number of children in union ( $\geq 3$ children) } \\
\hline None & 1.960 & 1.501 & $6.708^{* \star}$ & 0.890 \\
\hline $1-2$ children & $5.123^{* * *}$ & $2.519^{\star \star *}$ & $4.609^{\star \star \star}$ & $2.224^{\star * \star}$ \\
\hline \multicolumn{5}{|c|}{ Have at least one son in union ( $\mathrm{No}$ ) } \\
\hline Yes & $0.224^{* * *}$ & $0.388^{* \star *}$ & 0.832 & $0.626^{* *}$ \\
\hline
\end{tabular}

Note: ${ }^{* \star *} p<0.001 ;{ }^{* *} p<0.01 ;{ }^{*} p<0.05$; (References).

Several other control variables are associated with the risk of divorce and separation. Age at union is associated with risk of divorce. In Ouagadougou, men who married at young ages (before 25 years old) are nine times more at risk of divorce than those who married after the age of 30. In Lomé the differences are not significant for men, but women who married at a young age are less at risk of divorce than those who married at older ages ( $\geq 25$ years old). Contrary to what might be expected, ethnic heterogamy is not associated with higher risk of union breakdown (differences are not significant). Indeed, in Ouagadougou women in ethnically heterogamous couples have less risk of divorce than those in homogamous couples. This is consistent with results 
from previous research in Burkina Faso (Gnoumou Thiombiano and Legrand 2014). These results do not appear in Lomé, but the study of Locoh and Thiriat (1995) shows that in Togo rural areas, ethnic endogamy is reported to have a positive effect on marriage stability. The results also show that for men and women in both cities, remarriages are more at risk of divorce than first unions. For men, second unions and above have 3 and 7 times more risk of divorce than the first unions, in Ouagadougou and Lomé respectively. For women the risk is more than 6 times higher for second unions and above. Place of socialization also has a significant effect on union breakdown. Women who were socialized in Ouagadougou and Lomé have a higher risk of divorce than those who were socialized in rural areas. This finding has previously been observed in Burkina Faso (Gnoumou Thiombiano and Legrand 2014).

As expected, the results show that childless unions and those with one or two children are more at risk of divorce than those that have at least three children. This result is observed in both cities for men and women. For example, in Ouagadougou, childless women are seven times more at risk of union breakdown than those who have at least three children. It also appears that unions that have at least one son are less at risk of divorce than those that have no son. This result is consistent with the social role of boys in African societies.

\section{Discussion and conclusion}

In this article we studied union breakdown in two West African cities, Ouagadougou and Lomé, paying particular attention to three factors: cohort of the union, union celebration, and education. This study aims to contribute to our understanding of union breakdown in West Africa, especially in urban areas. The descriptive results show that the probability of divorce is higher in Lomé than Ouagadougou, but compared to other West African cities the probability of divorce is relatively low. These results show that the view that union breakdowns are common in West African countries is not verified in the context of this study. In recent research on divorce in Sub-Saharan Africa, Clark and Brauner-Otto (2015) also estimated that divorce is lower in Burkina Faso and Togo than in other West African countries.

According to the log-rank test, there is no significant difference between men and women in either city. However, for the variables 'union cohort,' 'union celebration,' and 'education' the differences between categories are significant in both cities. As observed at the national level in Burkina Faso (Gnoumou Thiombiano and Legrand 2014), in Ouagadougou younger union cohorts have a higher probability of divorce than the older cohort of women. However, for men in this city and for both men and women in Lomé the result is the opposite: The probability of divorce and separation is lower for 
older union cohorts than for the younger cohort. These findings are consistent with the national trends in several countries, including Togo. Analysing the DHS data in subSaharan Africa, Clark and and Brauner-Otto (2015) find that the proportion of first unions ending in divorce decreased between 1998 and 2013 in Togo. Informal union (without any celebration) and educated men and women have a higher probability of divorce than others in both cities.

The analysis of factors associated with union breakdown shows both similarities and differences between the two cities and between men and women. When other effects are controlled for, our results indicate that, excepted for men in Ouagadougou, there are no significant differences in divorce risk between union cohorts. Women in younger union cohorts do not have a higher risk of divorce than those in older cohorts. It seems that the period of union does not have a significant effect on the risk of divorce in these contexts. This result indicates that the younger generations of men and women, who claim free choice when choosing a spouse, have more stable unions than older cohorts. Free choice of spouse could be a cohesive factor for the couple and assure the stability of the union. However, the issue of exposure needs to be noted: People who married in the earlier periods have had longer exposure to divorce than those who married in the recent period (2000-2012). The case of men in Ouagadougou should be seen in the context of the period of revolution in Burkina Faso, when, in the spirit of revolution, women were held in high esteem and enjoyed high status, with the government messaging on gender equality and drafting the Code of the Person and the Family. In this period Burkina Faso was often presented as a pioneer in Africa in the promotion of women's empowerment.

Celebration of the union is an important factor associated with union breakdown in both cities. This result shows the importance of the family and society in union stability. Even when the spouse is freely chosen, the consent of families is necessary for the formalization of a union. There are several explanations of this effect. The solemnization of the union is an expression of its ties to and place in society and families are very involved in union celebrations, which are very important in strengthening ties between the couple. For women, the union is often considered as a social insurance, but this insurance is not guaranteed without the union being formalized. In Burkina Faso the man's opposition to celebrating a formal union is cited by women as a reason for divorce (Gnoumou Thiombiano 2014). When a union is formalized by solemnization, families will often play a role in reconciling spouses when conflict occurs. The celebration of a union seals the ties between families that consolidate the couple and make separation difficult. Note that given the legal context of the two countries, only civil unions have legal effects in case of divorce - the others have none. 
Education is also associated with union breakdown. Educated women in both cities and men in Ouagadougou have a higher risk of divorce than those who have no education. One explanation for this result is the difference between the two cities in education: men and women are less educated in Ouagadougou than Lomé. This result is consistent with other studies in West Africa (Antoine and Dial 2005). Indeed, if in Western countries research shows a negative relationship between education and divorce (De Graaf and Kalmijn 2006), in African countries it is the opposite - the relationship is positive. Note that the positive effect of education on divorce is consistent with the positive effect of education on other demographic events, such as childbearing, marriage, and other family dynamics. Education may be linked to better economic prospects, which can reduce the benefits of traditional gender roles within the marriage, specifically for women, by offering them better job opportunities (Vignoli and Ferro 2009). Educated women are able to dissolve an unhappy union because they are able to support their family economically. Education can also lead to questioning of the traditional roles of men and women in couples, which could be a source of discord in the couple and thus of divorce. As Locoh and Thiriat (1995) argue, divorce may be a strategy that women utilize in their quest for better social status.

Other union characteristics like the rank of the union are also associated with divorce. In both cities the risk of divorce is higher for remarriage than for first union. Note that social and family control in remarriages is low in the context of the study. However, as Martin and Bumpass (1989) argue, people in remarriage carry with them the characteristics that caused their first union breakdown. However, ethnic heterogamy does not seem to have an effect on the risk of divorce. The differences between ethnically homogamous and ethnically heterogamous unions are not significant, except for women in Ouagadougou. For women in Ouagadougou, as observed at the national level in Burkina Faso (Gnoumou Thiombiano and Legrand 2014), heterogamous unions have a lower risk of divorce than homogamous unions. Interethnic couples may have freely chosen their partners, which can favor good cohesion within the couple and reduce the risk of divorce. In addition, these couples may have fewer misunderstandings and conflicts than others.

Traditionally, in this study context people consider childbearing to be the main purpose of marital union, so the birth of children is of significant value. As expected, in this context fertility is a factor associated with divorce. Because of the value attached to children, infertility and low fertility are associated with a higher risk of divorce for men and women in both cities. Previous research suggests that infertility increases the risk of marital conflict and divorce (Fledderjohann 2012). The union having at least one boy reduces the risk of divorce. Couples without a son have a higher risk of divorce than those with at least one son. This result is explained by the social value of children, and especially boys, in African societies. Children may also constitute a barrier to union 
breakdown due to their parents' and particularly the woman's concern about the consequences of divorce for children. In the patrilineal societies of Ouagadougou and Lomé, the father and his family usually have custody of the children in the case of divorce.

There are some differences between men and women as regards place of socialization, ethnic composition of the couple (factors associated with divorce for women), and union cohort (factors associated with divorce for men). These results reveal that divorce is associated with cultural factors, particularly for women. This result may be related to gender relations within the societies in the study context, where women especially have to respect social norms. For other characteristics of the union (union celebration, rank of union) and fertility (number of children and having at least one son), it does not appear that there are clear differences between men and women.

This article contributes to research on union breakdown in urban West Africa, a subject that has received little attention in empirical literature. However, to better understand divorce in this context, where family plays an important role in union formation, we need to consider more cultural factors that could influence union breakdown. The qualitative approach can help us to better understand this issue.

\section{Acknowledgements}

The research project Family, Gender and Activities in sub-Saharan Africa was funded by the Agence Nationale pour la Recherche (ANR). I am grateful to the reviewers for their constructive comments, which significantly improved the paper. 


\section{References}

Amato, P.R. and Previti, D. (2003). People's reasons for divorcing: Gender, social class, the life course, and adjustment. Journal of Family Issues 24(5): 602-626. doi: $10.1177 / 0192513 X 03024005002$.

Amoateng, A.Y. and Heaton, T.B. (1989). The sociodemographic correlates of the timing of divorce in Ghana. Journal of Comparative Family Studies 20(1): 79 96.

Antoine, P. (2002). L'approche biographique de la nuptialité: Application à l'Afrique. In: Graziella, C., Vallin, J., and Wunsch, G. (eds.). Démographie: Analyse et synthèse II. Les déterminants de la fécondité. Paris: INED: 51-74.

Antoine, P. (2006). Analyse biographique de la transformation des modèles matrimoniaux dans quatre capitales africaines: Antananarivo, Dakar, Lomé et Yaoundé. Cahiers Québécois de Démographie 35(2): 5-38.

Antoine, P. and Dial, F.B. (2005). Mariage, divorce et remariage à Dakar et Lomé. In: Vignikin, K. and Vimard, P. (eds.). Familles au nord, familles au sud. Louvainla-Neuve: Academia-Bruylant: 205-232.

Antoine, P. and Nanitelamio, J. (1990). La montée du célibat féminin dans les villes africaines: Trois cas: Pikine, Abidjan et Brazzaville. Paris: CEPED (Les Dossiers du CEPED 12).

Assemblée Nationale Togolaise (2012). Loi $\mathrm{n}^{\circ}$ portant modification de l'ordonnance $\mathrm{n}^{\circ} 80-16$ du 31 janvier portant code des personnes et de la famille. Lomé: Assemblée Nationale Togolaise. https://togo.eregulations.org/media/loi-portantmodification-du-code-des-personnes-et-de-la-famille_1.pdf

Becker, S.G., Landes, E.M., and Michael, R. (1977). An economic analysis of marital instability. Journal of Political Economy 85(6): 1141-1187. doi:10.1086/2606 31.

Booth, A. and Edwards, J.N. (1985). Age at marriage and marital instability. Journal of Marriage and the Family 47(1): 67-75. doi:10.2307/352069.

Bumpass, L., Martin, T.C., and Sweet, J.A. (1991). The impact of family background and early marital factors on marital disruption. Journal of Family Issues 12(1): 22-42. doi:10.1177/019251391012001003. 
Calvès, A.E. (2016). First union formation in urban Burkina Faso: Competing relationship transitions to marriage or cohabitation. Demographic Research 34(15): 421-450. doi:10.4054/DemRes.2016.34.15.

Chae, S. (2013). Essays on family structure and marriage in sub-Saharan Africa. [PhD thesis]. Philadelphia: University of Pennsylvania, Graduate Group in Demography.

Cherlin, A.J. (1977). The effect of children on marital dissolution. Demography 14(3): 265-272. doi:10.2307/2060785.

Cherlin, A.J., Kiernan, K.E., and Chase-Lansdale, P.L. (1995). Parental divorce in childhood and demographic outcomes in young adulthood. Demography 32(3): 299-318. doi:10.2307/2061682.

Clark, S. and Brauner-Otto, S. (2015). Divorce in sub-Saharan Africa: Are unions becoming less stable? Population and Development Review 41(4): 583-605. doi:10.1111/j.1728-4457.2015.00086.x.

Clarke, L. and Berrington, A. (1999). Socio-demographic predictors of divorce. In: Simons, J. (ed.). High divorce rates: The state of the evidence on reasons and remedies, Research Series Volume 1. London: Lord Chancellor's Department: $1-37$.

Cleves, A.M., Gould, W.W., and Gutierrez, R.G. (2004). An introduction to survival analysis. College Station: Stata Press.

De Graaf, P.M. and Kalmijn, M. (2006). Change and stability in the social determinants of divorce: A comparison of marriage cohorts in the Netherlands. European Sociological Review 22(5): 561-572. doi:10.1093/esr/jcl010.

Dial, F.B. (2007). Le divorce, une source d'émancipation pour les femmes? Une enquête à Dakar et Saint-Louis. In: Locoh, T. (ed.). Genre et sociétés en Afrique: Implications pour le développement. Paris: INED: 357-372.

Fledderjohann, J. (2012). Zero is not good for me: An exploration of the implications of infertility in Ghana. Human Reproduction 27(5): 1383-1390. doi:10.1093/ humrep/des035.

Gnoumou Thiombiano, B. (2014). Causes et conséquences du divorce et de la séparation des couples au Burkina Faso: Les enseignements d'une enquête qualitative. In: Marcoux, R. and Antoine, P. (eds.). Le mariage en Afrique: Pluralité des formes et des modèles matrimoniaux. Quebec: Presses de l'Université du Québec: 230-249. 
Gnoumou Thiombiano, B. and Legrand, T.K. (2014). Niveau et facteurs de ruptures des premières unions conjugales au Burkina Faso. African Population Studies 28(3): 1432-1446. doi:10.11564/28-3-641.

Gnoumou Thiombiano, B., Legrand, T.K., and Kobiané, J.F. (2013). Effects of parental union dissolution on child mortality and schooling in Burkina Faso. Demographic Research 29(29): 797-816. doi:10.4054/DemRes.2013.29.29.

Hertrich, V. (2006). La polygamie: Persistance ou recomposition? Le cas d'une population rurale du Mali. Cahiers Québécois de Demographie 35(2): 39-69. doi:10.7202/018592ar.

Hertrich, V. (2007). Nuptialité et rapports de genre en Afrique: Tendances de l'entrée en union, 1950-99. In: Locoh, T. (ed.). Genre et sociétés en Afrique: Implications pour le développement. Paris: INED: 281-307.

Hertrich, V. (2014). Migration adolescente et autonomie féminine en matière de divorce en Afrique: Réflexions à partir d'un suivi de population au Mali. Cahiers Québécois de Démographie 43(2): 279-313. doi:10.7202/1027980ar.

Hoem, J.M. (1997). Educational gradients in divorce risks in Sweden in recent decades. Population Studies 51(1): 19-27. doi:10.1080/0032472031000149696.

Legrand, T.K. and Zourkaleini, Y. (2009). Consensual unions in Burkina Faso: Trends and determinants. Canadian Studies in Population 36(3-4): 267-294.

Lesthaeghe, R., Kaufmann, G., and Meekers, D. (1989). The nuptiality regime in subSaharan Africa. In: Lesthaeghe, R. (ed.). Reproduction and social organization in sub-Saharan Africa. Oakland: University of California Press: 238-337.

Locoh, T. (1976). La nuptialité au Togo: Evolution entre 1961 et 1970. Population 31(2): 379-398. doi:10.2307/1530449.

Locoh, T. (2000). Les facteurs de la formation des couples. In: Caselli, G., Vallin, J., and Wunsch, G. (eds.). Démographie: Analyse et synthèse II. Les déterminants de la fécondité. Paris: INED: 103-142.

Locoh, T. and Thiriat, M.P. (1995). Divorce et remariage des femmes en Afrique de l'Ouest: Le cas du Togo. Population 50(1): 61-94. doi:10.2307/1533793.

Marcoux, R. (1997). Nuptialité et maintien de la polygamie en milieu urbain au Mali. Cahiers Québécois de Démographie 26(2): 191-214. doi:10.7202/010231ar.

Marcoux, R. and Antoine, P. (2014). Le mariage en Afrique: Pluralité des formes et des modèles matrimoniaux. Quebec: Presses de l'Université du Québec. 
Martin, T. and Bumpass, L. (1989). Recent trends in marital disruption. Demography 26(1): 37-51. doi:10.2307/2061492.

Ministère de l'Action sociale et de la Famille (MASF) Burkina Faso (1990). Les droits de la famille au Burkina Faso. Ouagadougou: MASF and Ministère de la Justice.

Oppenheimer, V.K. (1994). Women's rising employment and the future of the family in industrial societies. Population and Development Review 20(2): 293-349. doi: $10.2307 / 2137521$.

Oppenheimer, V.K. (1997). Women's employment and the gain to marriage: The specialization and trading model. Annual Review of Sociology 23: 431-453. doi:10.1146/annurev.soc.23.1.431.

Pison, G. (1988). Polygamie, fécondité et structures familiales. In: Tabutin, D. (ed.). Population et sociétés en Afrique au sud du Sahara. Paris: L'Harmattan: 249278.

Ruggles, S. (1997). The rise of divorce and separation in the United States, 1880-1990. Demography 34(3): 455-466. doi:10.2307/3038300.

South, S. (1995). Do you need to shop around? Age at marriage, spousal alternatives, and marital dissolution. Journal of Family Issues 16(4): 432-449. doi:10.1177/ 019251395016004002 .

Takyi, B.K. (2001). Marital instability in an African society: Exploring the factors that influence divorce processes in Ghana. Sociological Focus 34(1): 77-96. doi:10.1080/00380237.2001.10571184.

Takyi, B.K. and Broughton, C.L. (2006). Marital instability in sub-Saharan Africa: Do women's autonomy and socioeconomic situation matter? Journal of Family and Economic Issues 27(1): 113-131. doi:10.1007/s10834-005-9006-3.

Thiriat, M.P. (1998). Faire et défaire les liens du mariage: Évolution des pratiques matrimoniales au Togo. Paris: CEPED (Les Études du CEPED n ${ }^{\circ} 16$ ).

Thornton, A. and Rodgers, W. (1987). The influence of individual and historical time on marital dissolution. Demography 24(1): 1-22. doi:10.2307/2061505.

Tilson, D. and Larsen, U. (2000). Divorce in Ethiopia: The impact of early marriage and childlessness. Journal of Biosocial Science 32: 355-372.

Van De Walle, E. and Baker, K.R. (2004). The evolving culture of nuptiality in subSaharan Africa. Paper presented at Perspectives on International Family Change 
Conference, Population Studies Center, University of Michigan, Ann Arbor, 3-5 June 2004.

Vignoli, D. and Ferro, I. (2009). Rising marital disruption in Italy and its correlates. Demographic Research 20(4): 11-36. doi:10.4054/DemRes.2009.20.4.

White, L.K. (1990). Determinants of divorce: A review of research in the eighties. Journal of Marriage and the Family 52(4): 904-912. doi:10.2307/353309. 
Gnoumou Thiombiano: Union breakdown in West African cities: The cases of Ouagadougou and Lomé 